\title{
Anthrovision
}

Vaneasa Online Journal

Vol. 7.2 | 2019

Epistemic Disobedience

\section{Provoking Film/Complicating Hierarchy}

An Ethnographic Film Script

\section{Theresa George}

\section{(2) OpenEdition \\ Journals}

Electronic version

URL: http://journals.openedition.org/anthrovision/6017

DOI: $10.4000 /$ anthrovision.6017

ISSN: 2198-6754

Publisher

VANEASA - Visual Anthropology Network of European Association of Social Anthropologists

Electronic reference

Theresa George, "Provoking Film/Complicating Hierarchy", Anthrovision [Online], Vol. 7.2 | 2019, Online since 10 November 2020, connection on 27 January 2021. URL: http://journals.openedition.org/ anthrovision/6017 ; DOI: https://doi.org/10.4000/anthrovision.6017

This text was automatically generated on 27 January 2021.

(c) Anthrovision 


\section{Provoking Film/Complicating Hierarchy}

An Ethnographic Film Script

Theresa George

\section{Prologue}

1 At the very beginning there was a desire to understand filmmaking as an occasion to travel and connect with people. In 2013, the directors Philipp Hartmann and Danilo Carvalho embarked on a journey where they produced some first shots that alluded to Virar mar in what was still a very enigmatic way. Only little by little did these hints condense into an idea, a working title, a first treatment, a shooting schedule. Movement emerged, a current that - like water carries sand and branches - involved further ideas, people, and technology. In order to 'explore more about the metaphorical potential of water resonating in everyday situations', our small, mobile film team has travelled to two regions since then: the desert-like landscape of the Sertão in northeast Brazil (2014 and 2017) and Ditthmarschen (2018), a coastal region in northern Germany that needs to be protected from flooding. Thus, the basic mode of Virar mar is a comparison: the awareness that one cannot be understood without the other, and that there is no fixed essence which lies between them. 'Water' is the extraordinary commonality. Water, which exists and does not exist everywhere.

2 My role in the making of Virar mar may be best described as a 'film set ethnographer' whose notes and observations were meant to help the team reflect more intensely on the journey, the filmmaking process, and lend inspiration to the film itself. By observing and writing field notes I was not particularly interested in translating a situation into a realistic text and thus entangling myself foremost with problems of representation. I rather wanted to 'imitate' what I was involved in. In other words, I was curious about how Virar mar would shape my perception and 'make' me write. This way, I felt closer to the film team's way of working and therefore closer to my research subject itself. 
In this article, I will focus on one particular encounter with a local film crew associated with the so-called Cinéma Popular in Brazil; a version of what you may know as Heimatfilm or amateur film. Josafá Duarte and his wife Noelhia are the central figures of a Cinéma Popular network consisting of other family members and villagers that has produced more than 40 films in the last nine years. Every film carries a political message addressing corruption, environmental pollution, or the false morality of church authorities. We got to know them in 2014, when Josafá casted us for his film 0 homem que queria enganar a morte. When we returned in 2017, it was a warm reunion. This time Philipp asked Josafá to direct $O$ centauro bronco by Mauricio Mendonça Cardozo, which is a Brazilian adaption of Theodor Storm's The rider on the white horse. In the final version of Virar mar we can listen to Josafá's answer. Standing under a big tamarind tree, he says: 'It's interesting, because we are living this moment of a fight about water. But to transform this to video, I'm not sure if it works. We will try and see what comes out.' - So, for five days, we tried it out and our film crew followed his instructions.

\section{Ways of Becoming}

4 The existence of a film is no lucky coincidence. The directors have to provoke it, tickle it, and actively create a path for it to come alive. Philipp and Danilo had to establish a financial, technical, and personal basis just so they could try to find out what Virar mar could look like. They skyped for hours and hours between the continents and wrote hundreds of pages to secure the funding to do this project. But their relationship had already started some 20 years ago. They first met at a concert in Fortaleza, where Danilo originates from and where Philipp was doing an exchange semester. Even today, they both vividly recall this evening when they became friends. Philipp may even have told Helena about this now fateful encounter when he asked her to join their film project and handle the cinematography. Helena, in turn, is based in Hamburg and, like Philipp, is a filmmaker. They both studied at the University of Fine Arts Hamburg and had already done a feature film together. On a warm summer night, it was Helena who introduced me, a cultural anthropologist fresh out of university, to Philipp. And when we got off the plane in Fortaleza on 30 April 2014, the four of us finally met. This encounter, as all the others, was immediately heart-warming because we share a personal pleasure, a common interest in film.

05/04/2014 - Very quickly, every one of us has found his usual seat in the car, which is true for cameras, tripods, suitcases as well. In the front seats, Philipp and Danilo are talking, laughing, and filming a lot with their $8 \mathrm{~mm}$ cameras. In the back, Helena and I are a little quieter. Especially me, listening. The outside world passes by. Time and again our gazes are sticking to something, detaching, projecting ... during the car rides we become closer, entre nous, with our equipment and accessories. And we realize that there are traces we have already left behind.

6 At this point, our team has yet to build up trust. But suddenly there is an inside and an outside. Moods emerge. We share some views and start to attune our gazes to the film, that is, for now, not more than a working title, an idea, some vague drafts.

7 My notebook, in turn, begins with a quote, conjuring good spirits: 
04/10/2017 '[The materials] are the reward of hard labour, it is true. Yet much is owed to chance as well. Not only does chance pervade the notebook, but certain moments of chance are formative of entire projects and paradigm shifts. These we celebrate as "discoveries" like Columbus "discovering" the New World on his way to what he thought was India. What a discovery!' (Taussig 2011: 57)

This media file cannot be displayed. Please refer to the online document http:// journals.openedition.org/anthrovision/6017

Video link https://vimeo.com/274915940

The clip shows our daily ride from Forquilha, the small town where our hotel is located, to Salgado, the home village of Josafá and his family. The Super 8 material is playfully shot by Danilo and Philipp. It looks beautiful, nostalgic, and somehow adventurous. And look, this is where coincidence already comes into play again. Perhaps one of these short glimpses would fit in with the collection of film material!? - The hope of finding images we do not know yet seems to go hand in hand with the fear of leaving an important one unfilmed.

11 After a 20-minute drive, we park the car right in front of Josafá's house. It lies next to Salgado's main square, a church and a football field, and is our base for the week. We quickly settle in and develop routines. One corner of the living room becomes our storage place and we have a daily lunch together. During siesta hours, we can have a rest, a chat, or watch a DVD together. We can also prepare for the next scenes, which are often shot on other farmsteads nearby. Sometimes the house itself turns into a film set. 'Working hours are from 10 to 4 pm', Josafá tells us. Whereas Saturday is a day off, because he is an Adventist.

This media file cannot be displayed. Please refer to the online document http:// journals.openedition.org/anthrovision/6017

Video link https://vimeo.com/274915365

The architecture of the house has even more qualities than giving us shelter: It blurs the inside and the outside. A breeze goes through the rooms to the terrace, light comes through the roof while shady walls and floors cool us down. And what is commonly dismissed as banal housekeeping does not happen without affecting the slowly emerging approach to our work.

07/19/2017 Philipp and Josafá are taking a seat at the kitchen table. They are directors; they have books, pencils, glasses. The furniture (fridge, sideboard, cupboard, stove) stands side by side in one corner as if the room was arranged especially for our shooting, leaving the fourth wall unfurnished. The tablecloth is forming waves. An ocean of plastic on which the flies can walk like Jesus over water ... Noelhia is preparing food in the kitchen that we cannot see while Philipp and Josafá start talking about the right text book passages for filming. Sunlight is coming and going. Helena and Danilo are communicating silently during recording. Food smells slowly start to fill the house and every once in a while Noelhia turns on the water tap. We can hear the drops falling. Here, she has more to do with water than the two directors. 
In the evenings we take the drive back to our hotel in Forquilha. The landscape now lies in darkness, the farmsteads appear only briefly and disappear again, like our thoughts about the day that lies behind us. Often we stop at a bar in Forquilha and have iced beer. Sometimes we just drive back to the hotel and turn up the music.

05/03/2014 Following the calm rhythm of the heat, my observations and thoughts move from one impression to the next. Altogether, it is impossible to keep an overview. Funnily enough, I meet Philipp in front of our rooms on this night. And he, too, can hardly remember what impressed him two hours ago. I seize the moment and pose some questions. So we talk for a while about how important it is to him that the team stays small and gets along well, while the day's material is copying to the hard drives.

Then we go to sleep.

07/19/2017 At the breakfast table we make plans for the day, solve technical problems etc. - But writing it down like this misses the point, the nuances, the anecdotes about our surrounding, the funny parts. A water dispenser stands on a small wooden cabinet on a nicely crocheted doily. On the top of it stands a vase with some plastic flowers in stale water. Obviously it is the best-decorated water dispenser I have ever seen. But no matter what you decide for - 'gelado' or 'natural' - 'It is peeing only tensely' (Helena).

After breakfast we leave for Salgado again.

This media file cannot be displayed. Please refer to the online document http:// journals.openedition.org/anthrovision/6017

Video link https://vimeo.com/274915998

Another shot of our route. This time filmed with the Black Magic towards the end of our stay. Now we know every curve, almost every vehicle, the palm trees, the hill. The melody to which we can hum along. The film has grown almost without being noticed. And suddenly images from yesterday begin to demand images from today. Virar mar has become more visible. And at the same time, despite all efforts, every frame lets something else sink into invisibility. It is one of the most basic constants of film that you simply have to accept. The success seems to rely on a constant negotiation of trust and resoluteness, intuition and planning, coincidence and 'hard labour' (Taussig 2011: 57). Not only for the film team, but for me, too.

\section{Filming Bodies}

07/20/2018 In Salgado I am drawn to the children, and they are drawn to my notebook. For them it is equally as mysterious as it is to me. ${ }^{1}$ 


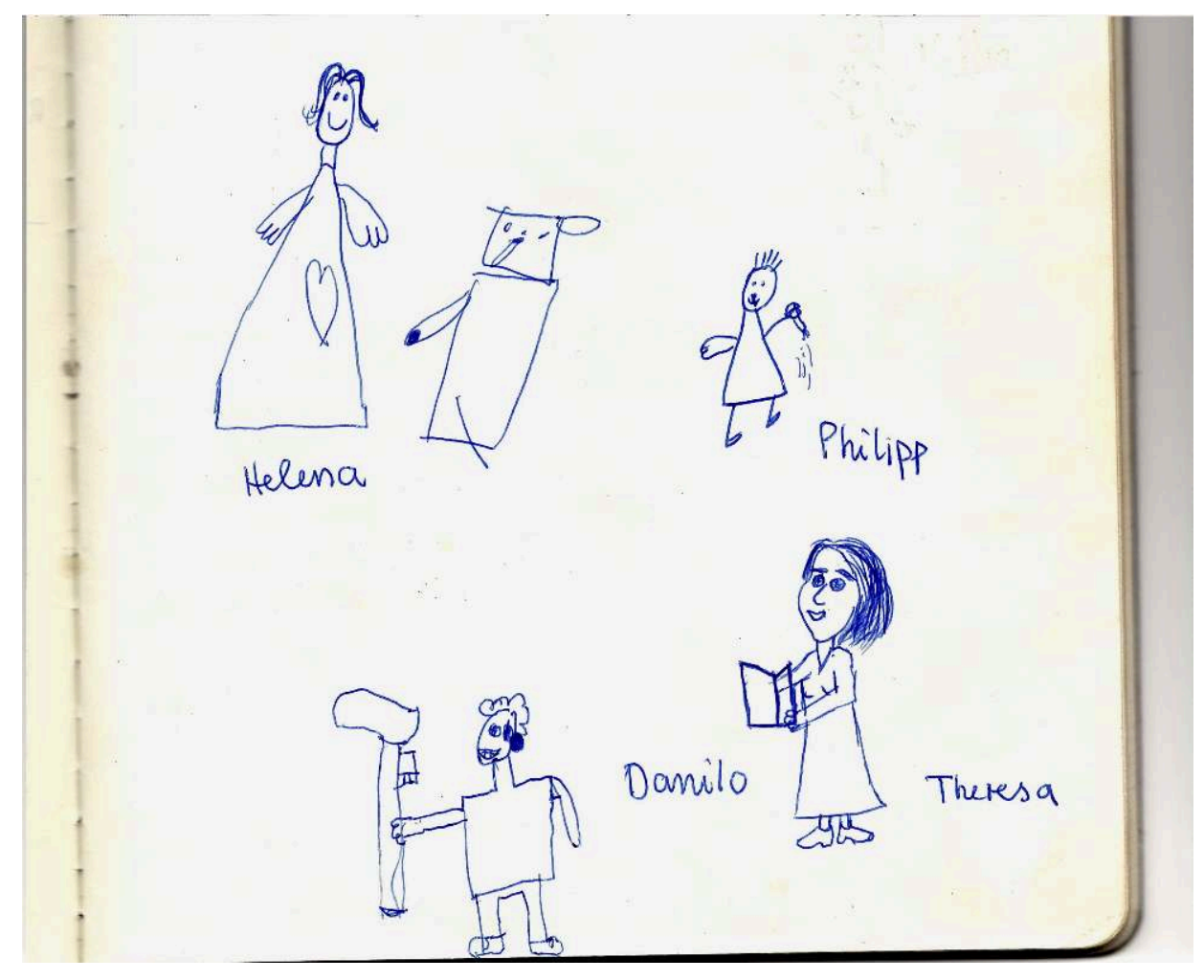

Photo by Theresa George, drawings by the children of Salgado

When I flip through my notebook today, I like to look at these drawings again and again. They remind me of how the children drew us: with high concentration, bent over the paper. Their eyes were watching us closely, and their hands were guiding the pen. But the emerging lines were not meant to mark our actual boundaries, instead they created something new. And like us filming and writing, the children were fascinated by the transformation of what they saw, by the relationship between their perception and their creation. When they were finished, they showed me their work with satisfaction. And I can't think of a better gift, for through their paintings I did indeed learn something very true about us.

Each of us carries an insignia by which we can be recognized. In fact, it is generally very easy to recognise a film crew. Experts could even make statements about budget and filming style at a glance. But, actually, a camera and a boom is all that's needed. If then, as in our case, a smoking director is added, then nobody will have any more doubts. A friend once even went so far as to claim that anyone planning an attack would only have to dress up as a film crew. Immediately, streets would be blocked and apartment doors opened without even being asked what for. Whether that's true or not, such filming bodies have, in any case, their own techniques, and requirements. One could write in detail about the equipment, about well thought-out bum bags, carabiners, colourful duct tape, baseball caps, or black clothing, so as not to be reflected by any unforeseen window. Not to begin with the cameras, objects, microphones, etc.

Besides, filming bodies are very active from head to toe and physically have to bear a lot. Helena, for example, has to constantly walk back and forth, kneel, lie down etc., in strong correspondence with the tripod, which facilitates the right perspective. In my 
documents, I also find a photo series of Danilo that I took during the shooting. It shows him in at least ten slightly different poses, which he performs with the recorder strapped on and a boom in his hand. The constant minimal shifts in weight, he will explain to me later, are one way to keep up with heavy equipment for so long. Inspired by yoga, he has also developed a breathing technique to simply avoid collapsing.

Another filmmaker friend compared to me the great physical effort of filmmaking and the constant carrying of heavy equipment with his idea of how wars must be like. And indeed, the multiform connections between the military and film culture have often been drawn. Just think of the expression 'shooting pictures'. And I make another connection when I look at the pictures I took of Danilo. Do they not resemble the early ethnographic films of Felix-Louis Regnault, which show us humans in various movements and work processes? And didn't these films reinforce a positivist zeitgeist, a view that turned people into objects? Moreover, Eberhard Schüttpelz linked this culturalisation of movement processes directly to the idea of being able to make movement more efficient, with marching as the first example (2010). This similarity may just be the paranoia of an anthropologist, but the general question of my role in this project - whose footsteps I'm following, which hierarchies I'm re-establishing accompany me constantly.

This media file cannot be displayed. Please refer to the online document http:// journals.openedition.org/anthrovision/6017

Video link https://vimeo.com/274915289

Philipp has taken this $16 \mathrm{~mm}$ clip of me: my insignias are the notebook, a pen, glasses and a parasol against the unusually intense sun. Towards the end of the clip you can see how Philipp frames me. Obviously, it's not only I who is perceiving, observing, noting and analysing. I was also being closely watched and fragmented. Watching the clip again and again makes me think: True, I still look like an anthropologist from the 1960s surrounded by an unknown wilderness. Except there seems to be no 'other' human being around anymore... so what the hell am I writing about!? Probably about Philipp filming me, which would indeed be a satirical comment on the ethnographic genre I favour. But I'm afraid I'm not getting off that easily.

This is because, despite everything, the recordings are very beautiful. And 'beauty can make you look more closely', as Helena would put it. Look at how the bright light hits the vibrant colours of the umbrella and eats them up! Everything is there in one and the same frame. Indeed, this incredible concreteness of film does have a liberating effect on me. It can show things side by side without making them an example of anything. It complicates them in a good way. ${ }^{2}$

So, let's watch another simple, but complicated clip.

This media file cannot be displayed. Please refer to the online document http:// journals.openedition.org/anthrovision/6017

Video link https://vimeo.com/275617104

This shot must have been made in passing. Philipp is cleaning the windscreen for the next shoot, while Helena is still sitting in the car. Maybe she is waiting for us to get ready. We cannot hear, only watch the boy commenting on Philipp. He's interested, but 
not too much. In this place, where the inside and outside are closely entangled, he stands calmly leaning against Josafá's car and passing the time. We cannot read his thoughts. The superficiality of film protects him. Moreover, the windshield is still smeared, and sometimes Philipp blocks our view. But here we, as spectators, definitely belong in a car more than anywhere else. From here, one does not have to move unprotected through unknown territory. To blur the ordinary without hiding anything, I think, holds true for this clip, as it does for Helena's cinematography in general.

\section{Taking Fun Seriously}

This media file cannot be displayed. Please refer to the online document http:// journals.openedition.org/anthrovision/6017

Video link https://vimeo.com/274916100

The two men you see in this clip are Josafá's brothers getting ready for a shoot. Every year they visit their home village Salgado for an annual festival. And every year Josafá seizes the opportunity to hire them as actors. So while our film team's work is primarily based on paid labour, a shared artistic-intellectual vision, and friendship, Cinéma Popular is mainly realised on the basis of family and neighbourhood. Because it is also voluntary, unpaid, and linked to other contexts and activities, a fast production process is essential. Actually, Josafá's fast directing has become his signature over the years. He himself says: 'I don't want to be a film's hostage for more than two weeks.' So let's go!

This media file cannot be displayed. Please refer to the online document http://

Video link https://vimeo.com/274915888

These recordings were made by Helena, who is now also working under Josafá's direction. In the foreground we see Ronaldo. He is one of Josafá's most important collaborators. So, unsurprisingly, he got the main role in the filming of 0 centauro bronco and - in this case - directs the work on the dam. For me, the whole power of Cinéma Popular lies in this scene, because life and film as well as fiction and reality are so close to each other that it would be a pointless hassle to analyse them as separate entities again. I nonetheless want to unravel one fundamental link between the two: The region of the Sertão, where we are located, is commonly known as the "poorhouse of Brazil'. Here, a few landowners in particular ensure that the majority of the population remains without any opportunities for advancement and often migrate. Moreover, Josafá's decision to make films is directly related to his involvement in the landless movement. For his part in the 'Movimento dos Sem Terra', he had been threatened with death, and consequently he shifted to the politically less dangerous work of collective film production. So, with this in mind, think again of the men working in the heat, shaping the barren land. 
This media file cannot be displayed. Please refer to the online document http:// journals.openedition.org/anthrovision/6017

Video link https://vimeo.com/438835063

Josafá's other films have more humour than 0 centauro bronco, because making funny films about unequal political power relations has the advantage of always being able to point out the harmlessness of a joke. Yet the political dimension of Josafá's work also affects the film business. The noise in the last clip is from Danilo using a saw to create a wind cage for a microphone. In a country where much has to be imported and in most cases little can be spent, improvisation is part of everyone's (film) life. On the other side, the products of Cinéma Popular are not meant to earn money in the first place.

Josafá (2014): 'Once I went to a black market and asked for a DVD copy of one of my films. The salesperson apologizes and feels caught. But I am actually disappointed that they don't sell my film. So I hand the salesman some DVDs. Only then he admits: "Yes, of course, we have your film!"'

Looking at the allocation of means of production, earning opportunities etc., there is a clear gap between us Germans and our Brazilian collaborators. In this respect, we are definitely in an unequal power relationship that cannot be talked down. However, film work that is participatory on both sides can at least help to create situations in which our gaze can be directed at a third foreign entity (the film), thus intervening in the postcolonial arrangement of those watching and being watched. ${ }^{3}$

41 One night, we set up a screen, two loudspeaker boxes, and some plastic chairs between our 'base' and the church. And as soon as the worship is over, the cinema starts.

This media file cannot be displayed. Please refer to the online document http:// journals.openedition.org/anthrovision/6017

Video link https://vimeo.com/274915577

So, you have just watched Josafá watching us in his production 0 homem que queria enganar a morte (The man who wanted to deceive the death) that we made in 2014. Philipp played a German water scientist and I acted as his wife. The roles are imaginative, but also draw on our European backgrounds and the resulting postcolonial relationship between us. In order to understand the funny parts and laugh about them, you have to be aware of this background. During the screening Josafá is - unlike us constantly talking and commenting on the film. The film itself doesn't seem to be the most important thing to him. Maybe it is more about having a good time with the film. However, the role change, our costumes, and the acting make us all laugh together, and I ask myself if his work as a director shares some features with that of a healer. One who captures the spirits of the past and present on the canvas, and displays them in a very respectful way for everyone's entertainment.

\section{The Film and its Margins}

After weeks of shooting, and long after our stay in Forquilha, I write: 
08/07/2017 When filmmaking becomes a totality on this trip, I start finding it brutal. The differences between film and life vanish. But I don't live in regard to an editing process. It is not only about interests, it is also about boredom...

Because of the many entanglements of life and film at play, it has taken me some time to discover the boundaries of film as a subject for my writing. But since it first caught my attention, I have been fascinated by how a film set establishes boundaries of different shapes and characteristics in a concrete spatial manner. This is especially because the shootings for Virar mar always took place at original locations, the transformation of a place into a film set was particularly impressive. At first, it seemed to be simple: a set comes into being when the film crew arrives. The director and cinematographer search for a picture, coordinate with the sound recordist and set up. Through them and between them a new spatiality comes into being, that one could call the 'core set'. It is always temporary and especially fragile, and it has to be protected against all kinds of intruders, like shadows, cars, dogs ... on the auditive level this protection gets even more complicated and the boundaries become invisible and fluid. So unsurprisingly, the routine before every shoot includes a 'Silêncio!'. Sometimes, however, those intruders allow for the unexpected.

Danilo: 'Right on arrival you can sense a clear division of the tonal space. On the right side there are rapids with various cascades. On the left side there are standing waters that form a rather empty tonal space. Maybe we want to work in the post production with this water as a place. So I have recorded various types of running water; falling, dropping. One that was "thicker", one a little more delicate, one kind of aggressive ... this way a chord with various notes comes into existence, so that we can compose this place. Anyhow, I don't record everything in order to have an archive afterwards. In contrast, I try to concentrate. For example on this bee, that was landing on the microphone, do you remember? I let her sit there. I like these kinds of things that just happen. They are somehow closer to truth, you know? We are working half staged half coincidentally. It is a mixture.'

Once it happened, that the whole film crew fell silent, when a singing voice approached from down the street, slowly getting louder and clearer. Luckily Danilo recorded the 'vaqueiro', a riding cattle shepherd, who sang a traditional 'aboiar' to herd his cows. Listen to the recording and, if you like, read on.

This media file cannot be displayed. Please refer to the online document http:// journals.openedition.org/anthrovision/6017

Audio link https://ia601407.us.archive.org/30/items/av-2020-vaqueiro-danilo-carvalho/ AV_2020_Vaqueiro_DaniloCarvalho.wav

The question of where a film set begins and where it ends is also a question about the boundaries of my field of research. It is not, and probably never has been, a lonely island. It is many-sided and multi-layered. And although my experience in the field seems to be holistic, not everything can be put into context. I hear the aboiar filling my tonal space more and more, even now in front of the computer. Danilo explained to me how rare this musical tradition of the Sertão has become. And that it has similarities to Arabic music. But instead of investigating this further, the American anthropologist Anna Lowenhaupt Tsing crosses my mind. She has described her field of study through 
'assemblages' (2015:22). And she compares the 'art of noticing' (2015:37) that you have to learn in order to perceive these assemblages, to listening to polyphonic music:

'When I first learned polyphony, it was a revelation in listening; I was forced to pick out seperate, simultanous melodies and listen for the moments of harmony and disharmony they created together. This kind of noticing is just what is needed to appreciate the multiple temporal rhythms and trajectories of the assemblage.' (Lowenhaupt Tsing 2015: 23).

This media file cannot be displayed. Please refer to the online document http:// journals.openedition.org/anthrovision/6017

Video link https://vimeo.com/274915747

The clip offers us an illusion. We might think that the film crew is departing the film location, leaving behind nothing more than a farm with drying laundry at the entrance. But of course the camera is still there, the sound is still being recorded. And indeed, after a couple of minutes, we have to come back to pick up Helena and Danilo. Besides its blurry boundaries, the film set of Virar mar is allowed to constantly change. The Cinéma Popular, however, uses the surroundings even more excessively as the scenery, the inhabitants as actors. In Salgado, for example, we often did shoots on local farms. The owners were happy to put their houses at our disposal. It is a cinema from the people for the people in the most concrete sense.

07/19/2017 At the end of the dusty road on a hill lies the farmstead. Windowless rooms protect us from the heat. Walls and floors seem to be made of the barren ferralsol soil of the surrounding area. We, ten to twelve bystanders, stay in the kitchen right at the entrance while the filmmakers start filming. It gets quiet: only the fire in the stove crackles. But the owner of the house can't be still, because she remains the hostess: she offers coffee and brings me a chair. Fresh sugar trickles into a tin. Mooing sheep. Then the counter-shot and 'Corte!' Applause. But H. is supposed to keep filming us, the audience. Slowly, the smell of coffee spreads. And then again, 'Silencio!' Two little boys hold their breath as if they were going for a dive. The filmmakers move into the next room. In the kitchen we are passing the time. Sweet coffee is served.

With time, I get bored documenting the routines of the 'core set' and sneak to the periphery. Here, the curious and those who are not needed at the moment gather. Children and adults alike. A new perspective opens up. I learn that waiting is an essential part of filmmaking. In addition, one must repeatedly be quiet, which allows for special forms of communication. A young woman starts writing messages in my notebook. She wants to know what I think of this and that. And this one, by the way, would really like me. 'It is simply nicer to spend time on a film set than anywhere else', someone sums it up for me.

I think of this statement now and remember that countless selfies were made on our set. We have served as a backdrop for Facebook profiles of friends, strangers, and even politicians, none of whom thought about 'stolen images'. Moreover, we were invited to local radio stations, had to make speeches, commented on football matches, and awarded medals. But we were also able to advocate for the international appeal of Cinéma Popular in order to ensure its local support. My initial unpleasant suspicion that we, as widely travelled white filmmakers, enjoy such a high reputation that this alone makes it worthwhile to be near us, has turned out to be a colonial fantasy. In 
their own way, the Brazilian people we met seem to have taken advantage of Virar mar as much as we have.

07/21/2017 For the next scene, we - the peripheral people - have to move closer to the house and here most of all we have to be quiet. Roger is being called in to play like he's leaving the set. So he walks away from the camera, passes us, goes through the yard gate and out into the street ... until Gisele calls him back. Who knows how far he would have gone otherwise?! Slowly I get hungry and Mateo gives me a taste of tamarind from the tree we're sitting under. How long can you hold the sourness without making a grimace? In the background Roger passes us several times and says 'Tchau!'. Incidentally, everyone says goodbye to him several times. We simply know how to play ourselves.

The last clip in this article shows the reverse angle to this entry. And for us, the spectators in front of a screen, Roger will be gone for real in less than one and a half minutes. So be warned, it will be a tough cut.

This media file cannot be displayed. Please refer to the online document http://

Video link https://vimeo.com/274916336

Weeks and months after the shoot, Philipp stays in intensive contact with our Brazilian collaborators. Again and again he sends out pictures from the editing table to everyone involved. And even before Virar mar celebrates its premiere, Philipp returns to Brazil to show it to the protagonists in the Sertão. Near Josafá's house, plastic chairs, loudspeakers, and a projector are set up once again, and Celio, a radio operator from Forquilha, who ultimately does not appear in the film at all, gives a speech on the unifying power of film. In solemn words, he says what film theorist Lucien CastaingTaylor (1996) meant when he wrote of films as shared spaces of experience that can provide a transcultural mediation.

\section{BIBLIOGRAPHY}

\section{Books and articles}

Bee, Julia. 2018. Ethnographien des Films und filmische Ethnographien. Überlegungen zur Frühen Visuellen Anthropologie. In Passionen des Realen. Menschenbilder in der Zwischenkriegszeit, Sonderheft Augenblick. Zons, Alexander, ed. Pp. 93-114. Marburg: Schüren.

Castaing-Taylor, Lucien. 1996. Iconophobia: How Anthropology Lost It at the Movies. Transition 69, 64-88.

Lowenhaupt Tsing, Anna. 2015. The Mushroom at the End of the World. Princeton: Princeton University Press. 
MacDougall, David. 1997. The Visual in Anthropology. In Rethinking Visual Anthropology. Marcus Banks and Howard Morphy eds. Pp 276-295. New Haven; London: Yale University Press.

Rancière, Jacques. 1987. Der unwissende Lehrmeister. Fünf Lektionen über die intellektuelle Emanzipation. Wien: Passagen Verlag.

Schüttpelz, Eberhard. 2010. Körpertechniken. Zeitschrift für Medien- und Kulturforschung (1), 101-120.

Storm, Theodor. 2006. O centauro bronco. Translated by Mauricio Mendonça Cardozo. Curitiba : Ed. UFPR

Taussig, Michael. 2011. I swear I saw this - Drawings in Fieldwork Notebook, namely my own. London: The University of Chicago Press.

Films

Carvalho, Danilo, and Hartmann, Philipp, dirs. 2020. Virar Mar. Flumenfilm, Danilo Carvalho, Sancho Punta and Tardo Filmes (production). 85 min.

\section{NOTES}

1. This entry is inspired by Taussig's writing about the connection between 'to draw' and 'to be drawn to' (2011: 13).

2. The very different points of view regarding the possible gain of knowledge through film is reflected in several key texts of visual anthropology. David Mac Dougall (1997), for example, has traced the early debates, and Lucien Castaing-Taylor (1996) the later ones. In her essay 'Ethnographies of Film and Cinematic Ethnographies' (2018, author's translation), the media scientist Julia Bee (2018) has furthermore written about a relational and performative reality, which is created under filmic conditions. This way, she argues, the question of realism is a question of participation, which I also want to claim for Virar mar.

3. I have freely adopted the shared-learning view towards a third party from Jacques Rancière's (1987) reflections on a pedagogy that does not view the teacher-student relationship in dichotomies of active-passive, knowing-unknowing, superiorsubordinate. Instead, he advocates an egalitarian relationship between all intelligences, each of which is able to acquire and share knowledge independently through (re)translation. The role of teachers is therefore limited to encouraging this.

\section{ABSTRACTS}

In 2014 and 2017, I accompanied the filmmakers Philipp Hartmann, Danilo Carvalho, and Helena Wittmann to the Sertão in the northeast of Brazil. In this desert-like region we gathered the material for Virar mar (2020), an experimental documentary about the meaning of water - its uses, politics, metaphorical potential, and (his)stories. My role in the team may be best described as a 'film set ethnographer' whose notes and observations were meant to reflect more on the journey, the film process, and perhaps even lend inspiration to the film itself. The encounter 
with another film team complicated the distinction between life and filmmaking as well as between fiction and reality. Thus, political, cultural, and aesthetic hierarchies also became blurred. By re-examining and reassembling the raw material we gathered on this journey - film, video, sound, and text - I hope to provoke sensual as well as critical readings of our findings.

En 2014 et 2017, j'ai accompagné les cinéastes Philipp Hartmann, Danilo Carvalho et Helena Wittmann au Sertão, dans le nord-est du Brésil. Dans cette région désertique, nous avons rassemblé le matériel pour Virar mar (2020), un documentaire expérimental sur la signification de l'eau - ses utilisations, sa politique, son potentiel métaphorique et ses (ses) histoires. Mon rôle dans l'équipe peut être décrit comme celui d'une "ethnographe de plateau de tournage" dont les notes et les observations étaient destinées à réfléchir davantage sur le voyage, le processus cinématographique, et peut-être même à donner de l'inspiration au film lui-même. La rencontre avec une autre équipe de tournage a compliqué la distinction entre la vie et le cinéma ainsi qu'entre la fiction et la réalité. Ainsi, les hiérarchies politiques, culturelles et esthétiques sont devenues floues. En réexaminant et en réassemblant la matière première que nous avons recueillie au cours de ce voyage - film, vidéo, son et texte - j'espère provoquer des lectures sensuelles et critiques de ces observations.

En 2014 y 2017, acompañé a los cineastas Philipp Hartmann, Danilo Carvalho y Helena Wittmann al Sertão por el noreste de Brasil. En esta región desértica reunimos el material para Virar mar (2020), un documental experimental sobre el significado del agua: sus usos, política, potencial metafórico y sus historias. Mi papel en el equipo puede describirse mejor como un "etnógrafo del evento fílmico" cuyas notas y observaciones estaban destinadas a reflexionar más sobre el viaje, el proceso de la película y tal vez incluso brindar inspiración a la película en sí. El encuentro con otro equipo de filmación complicó la distinción entre la vida y el cine, así como entre la ficción y la realidad. Así, las jerarquías políticas, culturales y estéticas también se desdibujaron. Al reexaminar y reensamblar la materia prima que reunimos en este viaje (película, video, sonido y texto), espero provocar lecturas sensuales y críticas de nuestros hallazgos.

\section{INDEX}

Keywords: filmmaking, visual anthropology, artistic research, sensual anthropology, space, postcolonialism, activism, Brazil

Mots-clés: realisation filmique, anthropologie visuelle, recherche artistique, anthropologie des sens, espace, post-colonialisme, militantisme, Brésil

Palabras claves: realización cinematográfica, antropología visual, investigación artística, antropología sensual, espacio, poscolonialismo, activismo, Brasil

\section{AUTHOR}

\section{THERESA GEORGE}

M. A., freelance film anthropologist

th.george@posteo.de 